\title{
Prion-like aspects of cerebral amyloidosis
}

\author{
Mathias Jucker ${ }^{*}$, Lan Ye, Sarah Fritschi \\ From Molecular Neurodegeneration: Basic biology and disease pathways \\ Cannes, France. 10-12 September 2013
}

The commonality of many neurodegenerative disorders is the predictable temporal occurrence and progression of specific aggregated proteins in the brain. The hallmark proteopathy is Alzheimer's disease in which aggregated amyloid- $\beta$ peptide $(A \beta)$ is deposited in the brain parenchyma as amyloid plaques. Multiple evidence suggests that $\beta$-amyloidosis is induced by aggregated $A \beta$ which can spread within and among brain regions and act as corruptive templates (seeds) that induce a chain-reaction of $A \beta$ misfolding and aggregation. The insight that the prion paradigm may also apply to cerebral $\beta$-amyloidosis and other proteopathies suggests new avenues in search of biomarkers and novel therapeutic strategies.

Published: 13 September 2013

doi:10.1186/1750-1326-8-S1-O21

Cite this article as: Jucker et al:: Prion-like aspects of cerebral

amyloidosis. Molecular Neurodegeneration 2013 8(Suppl 1):O21.

Submit your next manuscript to BioMed Central and take full advantage of:

- Convenient online submission

- Thorough peer review

- No space constraints or color figure charges

- Immediate publication on acceptance

- Inclusion in PubMed, CAS, Scopus and Google Scholar

- Research which is freely available for redistribution

Submit your manuscript at www.biomedcentral.com/submit

\section{() Biomed Central}

